\title{
Leaf Reddening in Bt Hybrid Cotton
}

\author{
Ambati Ravinder Raju* \\ ICAR-Central Institute for Cotton Research, India
}

Submission: December 16, 2016; Published: January 26, 2017

*Corresponding author: Ambati Ravinder Raju, ICAR-Central Institute for Cotton Research, Nagpur 440010 (MS), India, Tel: 99750 55630/7385709325; Email: bumaraju@gmail.com

\section{Introduction}

Mahyco Monsanto Biotech Co (MMB) had commercially introduced Bt cotton hybrids directly under its supervision in 2002 with selected farmers under supplemental irrigations Mohan \& Manjunath [1]. Bt hybrid cotton had initial hiccups like lower seed cotton yield, poor micronaire, leaf reddening besides lower price realzation by the early innovative farmers under rainfed and irrigated conditions except boll worm protection Ramanujam and Kuraganti, 2004 Stone [2]. Bt hybrid cotton was well adopted by small and marginal farmers under rainfed conditions into shallow to medium deep soils in Maharashtra state reached $65 \%$ of the cotton area in 2007 due to reduced expenditure on boll worms, synchronized boll bursting with seed cotton yield advantage of $5 \mathrm{q} \mathrm{ha}^{-1}$ with $30 \%$ more boll retention and 20 days earliness over non bt hybrid cotton Ramasundaram [3]; Hebbar et al. [4].

Reddening of leaves is a a physiological disorder in early Bt hybrid cotton genotypes except medium and late duration hybrids with Cocker 312 background, induced by different biotic, abiotic and nutritional stresses at peak boll development stage, with strong accumulation of anthocyanins and drop of chlorophyll content, increase of proline content and peroxidase activity Edreva et al. [5]; Kumar \& Swamy [6], Prakash et al. [7]. Earliest report of leaf reddening was reported by NGOs as early as 2003-04, however it went unheard by public and private sectors Raju \& Thakare [8], later it was confirmed by many authors about increase in management costs of sucking pests and foliar diseases besides decline in yield Raju \& Thakare [9]; Better crops [10]. Seed cotton yield reduction due to leaf reddening was estimated and reported by different authors around 15-20\% further aggravated by foliar diseases and unfavourable rainfall distribution reaching a yield reductions up to $50 \%$ Raju \& Thakare [9]. Bt hybrid cotton profitability had also eroded after the record highest prices in year 2011 with further increase in labour costs and reduction of imports by China Raju \& Thakare [9].

\section{Forgotten better management practices (BMPs)}

Surveys conducted by the investigators found no application of animal manures, tank silt animal pennings etc due to the higher cost or short supply. Commercial cultivation of Bt hybrid cottonsoybean-gram /wheat system under imbalanced nutrition in the absence of K, S, Mg, Mn, Zn, B application resulted in permanent replacement of soybean due to viral disease (YMV) and partial replacement of Bt hybrid cotton by leaf reddening. Farmers returns were still compensated up to $40 \%$ from stripcropped pigeon pea (6-8:1/2). BMPs remained on paper itself as the gulf between technology developers and users was widened with poor extension linkages and lack of interest of technology developers to go in for participatory mode.

\section{Role of genotypes}

Leaf reddening incidence was more pronounced with early $\mathrm{Bt}$ hybrid cotton genotypes than medium, late duration and stay green hybrids like Vithal, Green Gold, GK 202, Mallika etc vis a vis nonBt hybrid cotton genotypes. The reduction of chlorophyll content in reddening affected leaf was maximum in Bt hybrid cotton MRC6301. Anthocynine content was increased in reddening affected leaves up to $5.0 \%$ at square formation stage Pagare \& Durge [11]. Long duration BG II Bt hybrid cotton Neeraja produced lowest red leaves and maximum of 25\% in short duration Bunny NCS 145 Hosmath et al. [12]. Long duration BG II Sigma Bt hybrid cotton recorded more seed cotton yield ha ${ }^{-1}$ with high anthocynin pigment indicating starvation of required nutrients which were forced to translocate to sink Khadangle et al. [13].

Susceptible genotype Bunny NCS 145 BG II. Long duratio Bindaas BG II 7213-2 considered as tolerant to leaf reddening Janagouder [14]. Visual observations recorded at 108 DAS indicated BG II hybrids Ankur 216, Ankur 3042, Ankur Jai, Atal, Express, MRC 7301, Paras Krishna, Uttam, VICH 303 and VICH 304 were unaffected by leaf reddening Nagarale [15]. Anthocyanin content in reddening affected leaves of MRC-6301 was maximum compared to reddening affected leaves of NSC-145 BG II hybrid Pagare \& Durge [16]. Jackpot, MRC-7347, Marvel and MRC-7351 were found tolerant to sucking pests and reddening symptoms. Bt hybrids such as RCH 2, RCH 530, Brahma, Arya and Bunny were highly sensitive to insect-induced reddening Ghante et al. [17]. 


\section{Role of harmones and PGR on root activity}

Soil moisture conservation practices, super gels, humic acid seed treatment, tank silt and animal manures soil application, foliar application of cyto-kinins, root activating harmones like IBA, humic acid, Annie sheba \& Manikandan [18] and other bio-stimulants for enhanced root activity must be evaluated for reducing the leaf reddening Raju et al. [8].

\section{Role of shoot activity}

Humic acid extended shoot and leaf growth with its harmonal activity and delayed boll bursting and senescence. Growth retardent CCC foliar application twice reduced plant height and leaf growth further delayed leaf reddening by one month in Hy 6 Bt hybrid cotton Raju et al. [8].

\section{Role of sink / boll load}

Early and concentrated boll retention and high fruiting efficiency in Bt hybrid cotton resulted in lower rate and quantity of dry matter plant- 1 with shallow roots $(30 \mathrm{~cm})$. Higher sink in Bt hybrid cotton leads to lower source to sink ratio, faster senescence and crop maturity Hebbar et al. [4]. Sometimes, the increased assimilate demand of early and higher fruit retention reduces the resources for continued root growth, leading to early maturity and reduced yields.

\section{Role of sucking pests}

July and August months' leaf reddening was due to $70 \%$ by jassids and $10 \%$ by thrips in early maturing Bunny Bt hybrid. BG II Bt hybrids MRC 7301, Atal, Classic , Krish, Ryan, SP 504, Namaskar, Madhura, VICH 312 registred lower population levels of sucking pest, and also lesser leaf reddening and higher yield levels Nagarare et al. [15].

\section{Role of diseases}

Foliar leaf spot diseases like Alternaria, Myrothecium, Xanthomonas malvacearum, grey mildew besides Fusarium and Verticillum wilts also produces yellowing and discoloration, leaf spots, necrosis and bronzing symptoms in $20-30 \%$ of the leaf area of green leaf foliage in the absence of any plant protection measures against them Santosh [20]. One or two sprays propiconazole was very effective against foliar diseases in Bt hybrid cotton Janagouder [1], Raju [8].

\section{Role of major nutrients}

Mobile elements measured in the index leaves which shown symptoms were often misleading to that of nitrogen content of healthy leaves in Bt hybrid cotton ranged from 1.17 to $1.30 \%$ in reddening affected leaves at square formation stage and thereafter progressively reduced upto boll bursting stage as reported by Pagare \& Durge [16] needs relook in comparison to those authenticated by Raju \& Thakre [9] in Bt hybrid cotton. Carbohydrate percentage 0.99 to $1.05 \%$ was maximum in reddening affected leaves as compared to healthy leaves of all the Bt cotton hybrids from square formation stage reddening of leaves were observed in Bt cotton genotypes
Pagare \& Durge [11]. Leaf reddening significantly reduced with $25 \%$ higher dose of NPK fertilizers but non significan response was observed by Raju \& Thakare (2010) in Bunny Bt hybrid cotton. The extent of reduction in leaf reddening was125 and $150 \%$ RDF was 15 and $30 \%$ respectively. Leaf reddening was $2.5 \%$ with $100 \%$ RDF Santosh [19]. Redness of leaves was also caused by potassium starvation is a major problem in Bt hybrid cotton. Leaf redness symptoms in cotton, leads to interference and misleading practices from time to time. K uptake in calcareous soils is difficult, therefore, it should be ensured to be within the critical limits prescribed for in the cotton leaf Anonymous [20]; Santosh [19].

\section{Role of secondary nutrients}

Excess of exchangeable $\mathrm{Ca}$ in calcareous soils leads to $\mathrm{Mg}$ and $\mathrm{K}$ deficiency resulting in leaf reddening. Leaf Magnesium was reduced by 0.44 to $0.46 \%$, in reddening affected leaves Pagare \& Durge [21]. Nutrient supply through foliar spray showed that if $2 \%$ Urea $+0.2 \% \mathrm{MgSO}_{4}+0.1 \% \mathrm{ZnSO}_{4}$ sprayed twice enhance high level of chlorophylls which kept under check the accumulation of anthocaynin content of Sigma Bt hybrid cotton leaf Khadangle et al. [13]. Reddening affected leaves magnesium content level was slightly lowered than that of healthy leaves Pagare \& Durge [16]. Leaf reddening significantly reduced with foliar sprays of $\mathrm{MgSO}_{4}+$ KNO3, $\mathrm{MgSO}_{4}+19: 19: 19$ and MgSO4 thrice @1\% combined with initial soil application of MgSO4 @ $25 \mathrm{~kg} \mathrm{ha}^{-1}$. Leaf reddening 18.7 and 16.2 per cent with three foliar sprays of $\mathrm{MgSO}_{4}+\mathrm{KNO}_{3}$ and MgSO4 +19:19:19 respectively, along with soil application of $\mathrm{MgSO}_{4}$ @ $25 \mathrm{~kg} \mathrm{ha}^{-1}$ Santosh et al. [19]. Minimum intensity of reddening in Bt hybrid cotton was observed in $100 \% \mathrm{RDF}+$ foliar sprays with $1 \% \mathrm{KNO}_{3}$, which suggest that at boll development stage the application of nitrogen and potassium were helpful for controlling the reddening in Bt hybrid cotton. However, the application of 100 $\% \mathrm{RDF}+1 \% \mathrm{MgSO}_{4}$ spray was found to be the best for highest content of chlorophyll as well as yield of Bt hybrid cotton Masram et al. [22]. Foliar spray of $\mathrm{MgSO}_{4}(1 \%)$ is often recommended as a corrective measure. Field experiments were conducted at Faridkot and Bathinda indicated highest seed cotton yield (3064 $\mathrm{kg} \mathrm{ha}^{-1}$ ) with application of $\mathrm{MgSO}_{4} @ 1.5 \%$ thrice due to reduction in leaf reddening (8\%) when leaf Mg content was below critical limits Singh et al. [23]. In mera gaon mera gaurav programme both calcareous and non calcareous soils 850 demonstrations in the farmers fields were conducted with non significant improvement in seed cotton yield and leaf reddening by any of the soil and foliar application of N, P, K, $\mathrm{Zn}, \mathrm{Mg}, \mathrm{B}$ and humic acid except change in leaf color quality for one month probably due to fresh growth of new leaves Raju et al. [8].

\section{Role of micronutrients}

Maximum reduction of red leaves were with the soil application of @ 120-70-40 NPK in combination with Zn and B @ 4 and 1.5 kg ha $^{-1}$, respectively Gandhi et al. [24]. However, the direct effect on leaf reddening major from and micronutrients could not be verified in farmers fields but helped only in putting up more fresh growth, thereby reduces percent red leaves in Bt hybrid cotton Raju et al. [8]. 


\section{Role of Growth Regulators}

Plant growth regulators application to modify early and mid season growth is very essential in the management of leaf reddening through reduction in the shoot biomass and increase in root growth for continued uptake throughout the boll development. There is potential to influence present seed cotton yield levels of $560 \mathrm{~kg} \mathrm{ha}^{-1}$ lint with optimum adoption. Plant growth regulators have the potential to promote square and boll retention, higher nutrient uptake, and keeping vegetative and reproductive growth in harmony to improve lint yield and quality. Gibberellins are associated with increase in fruit retention in cotton.

\section{Role of cytokinins}

Cytokinins can also delay aging of leaves, allowing longer photosynthetic activity with reduction in fruit abscission and also can promote cell division and enlargement of stems, leaves and fruit. PGR IV may be options for growers who want to pursue high yields through a more intensive management approach. It would be advisable to apply the materials early in the growing season to promote early growth, such as in-furrow (PGR IV) or match head square treatments, then use Pix or Mepichlor after bloom to slow vegetative growth and force a timely cut out. Over an 8-year period, PGR IV on cotton if applied 2 to 4 ounces per acre beginning at match head square and applying weekly for a total of four applications has produced 115 pound lint yield from foliar applications.

Cytokinin may be most beneficial under stressed conditions to maintain proper boll set and retention, promote earliness and develop a better root system Albers \& Schnakenberg [25]. Growth chamber studies revealed that the in-furrow applications of PGR-IV @ $1.13 \mu \mathrm{L} /$ plant dramatically increased root length $(+47 \%)$, root dry weight $(+29 \%)$, number of lateral roots per plant $(+75 \%)$, and nutrient uptake one week after planting. These differences were still apparent five weeks later at pinhead square but to a lesser degree. Positive effect of PGR-IV on root growth and accelerated earlyseason growth could have very substantial benefits in reducing the leaf reddening in Bt hybrid cotton production Oosterhuis \& Zhao [26,27].

\section{Conclusion}

Integrated module comprised use of sucking pest-tolerant cotton hybrid (Ankur 216, Ankur 3042, Ankur Jai, Atal, Classic, Express, GK 202, Green Gold, Jackpot, Krish, Mallika, Marvel, MRC 7301, MRC-7347, MRC-7351 Namaskar, Madhura, Paras Krishna, Ryan, SP 504, Uttam, VICH 303 VICH 304, VICH 312 and Vithal) avoiding cultivation of Sucking pests sensitive hybrids such as Arya, Brahma, Bunny, RCH 2 and RCH 530. Balanced and timely soil application of macro- and micro-fertilizers as per recommendation based on site-specific soil test results; threshold-based management of sucking pests, especially leafhoppers, using systemic insecticides; foliar applications of Mancozeb 75WP at $2 \mathrm{~g} / \mathrm{L}$ against leaf spot disease; three foliar applications of water-soluble multi nutrient mixtures at $4 \mathrm{ml} / \mathrm{L}$ during 60, 75 and 90 DAS and weeding during first 40 DAS proved best for the management of Bt cotton reddening Ghante et al. [17].

\section{References}

1. Mohan KS, Manjunath TM (2002) Bt cotton - India's first transgenic crop. J Plant Physiol 29: 225-223.

2. Stone GD (2011) Field versus farm in Warangal. Bt cotton, higher yields, and larger questions. World Development, Elsevier, Netherlands.

3. Ramasundaram P (2005) The performance of Bt cotton hybrids in India. ICAC Rec, India, 23: 17-18.

4. Hebbar KB, Rao MRK, Khadi BM (2007) Synchronized boll development of Bt cotton hybrids and their physiological consequences. Current science 93(5): 693-695.

5. Edreva A, Gruel A, Gesheva E, Hakerleder H (2002) Reddening of cotton (Gossypium hirsutum L.) Leaves. Article in Biologia Plantarum 45(2): 303-306.

6. Kumar SGV, Swamy SVSG (2014) A duo-decennium of Bt cotton adoption in India - An overview Current Biotica 8(3): 322-340.

7. Prakash AH, Kranthi KR, Nagrare VS, Sandhya Kranthi, Vinita Gothmare (2014) Cotton leaf reddening-A systematic damage caused by the use of Methomyl in cotton. Cotton Research Journal 6(1): 83-88.

8. Raju AR, Majumdar G, Anuradha Narala, Amuda (2016) Mera gaon Mera Gaurav, Kalmeshwar cluster Report, ICAR-CICR, Nagpur, India.

9. Raju AR, Soniya K, Thakare (2012) Nutrient management on FUE, red leaf, fibre properties of Bt hybrid cotton (Gossypium hirsutum). Indian Journal of Agronomy 57(4): 13-19.

10. Better Crops (2014) Crop Nutrient Deficiency Photo Contest Winners 2013. Better Crops 98 (1): 16-17.

11. Pagare GA, Durge DV (2011) Pigment analysis studies with reference to leaf reddening in Bt cotton. International Journal of Plant Sciences 6(1): 42-44.

12. Hosmath JA, Biradar DP, Patil VC, Palled YB, Malligawad LH, et al. (2012) Performance of Bt and non-Bt cotton genotypes under leaf reddening malady situation. Karnataka J Agric Sci 25(1): 36-38.

13. Khandagale G, Bhosale M, Bhamare V, Khandagale V (2011) Effect of nutrients on reddening of Bt and non Bt cotton hybridsParbhani, Maharastra, India World Cotton Research Conference on Technologies for Prosperity, India.

14. Janagoudar BS (2015) Leaf reddening index as an indicator of leaf reddening malady in Bt cotton hybrids: causes and remedies. $12^{\text {th }}$ Meeting of the Inter-regional cooperative research network on cotton for the mediterranean and middle east regions Sharm El-Sheikh, Egypt.

15. Nagrare VS, Deshmukh AJ, Bisane AK (2014) Relative performance of Bt-cotton hybrids against sucking pests and leaf reddening under rainfed farming. Entomol Ornithol Herpetol 3:134.

16. Pagare GA, Durge DV (2010) Biochemical studies with reference to leaf reddening in Bt cotton. Annals of Plant Physiology 24 (1): 1-3.

17. Ghante VN, Chowdary R, Bheemanna M, Hosamani A, Kumar R (2015) Integrated management of insect-induced reddening in Bt cotton hybrids Chapter New Horizons in Insect Science: Towards Sustainable Pest Management. pp. 277-282.

18. Annie Sheeba J, Manikandan A (2012) Role of leaf phytochemicals in cotton leaf reddening and plant responses to management through growth chemicals, nutrients and insecticides.

19. Santhosh UN (2014) Presentation on theme: Presentation transcript: SEMINAR-II ON Leaf reddening in cotton and its management.

20. http://www.toros.com.tr/dosyalar/ciftcidostu/gruplar/1_53071878_ toros_go_pamuk_su.pdf

21. Pagare GA, Durge DV (2010) Pigment analysis with reference to leaf reddening in Bt cotton. Annals of Plant Physiology 24 (1): 102-103. 
22. Masram RS, Patil AA, Kadam SR, Shewale BY (2015) Effect of fertilizer levels on leaf reddening in Bt and non-Bt cotton. Asian J Soil Sci 10(1): $1-12$

23. Singh KS, Malik P, Rathore, Singh S (2015) Ameliorating leaf reddening and enhancing Bt cotton productivity through foliar application. Ecology Environment and Conservation 21(3): 1535-1539.

24. Gandahi AW, Panhwar K, Gandahi R, Sarki MS, Buriro M (2016) Amelioration of cotton leaf reddening with boron and zinc application through balanced nutrient management practices. Sarhad Journal of Agriculture 32(4): 275-281.
25. Albers DW, Schnakenberg CT (1994) Plant Growth Regulators for Cotton.

26. Oosterhuis DM, Zhao D (1994) Increased root length and branching in cotton by soil application of the plant growth regulator PGR-IV. Plant and Soil 167(1): 5-56.

27. Santosh UN, Satyanarayana Rao, Shantappa Duttarganvi, Haleyapati AS, Koppalkar BG (2014) Effect of leaf reddening management practices on sucking pests populations and yield of Bt cotton (Gossypium hirsutum 1.). under irrigation Bioinfolet 11(1A): 105-108.

\section{Your next submission with Juniper Publishers will reach you the below assets}

- Quality Editorial service

- Swift Peer Review

- Reprints availability

- E-prints Service

- Manuscript Podcast for convenient understanding

- Global attainment for your research

- Manuscript accessibility in different formats

( Pdf, E-pub, Full Text, Audio)

- Unceasing customer service

Track the below URL for one-step submission https://juniperpublishers.com/online-submission.php 